\title{
SEJARAH PERKEMBANGAN SISTEM PENDIDIKAN MADRASAH SEBAGAI LEMBAGA PENDIDIKAN ISLAM
}

\author{
Yayah Chairiyah \\ Madrasah Aliyah Negeri (MAN) 2 Ponorogo \\ yayahchairiyah66@gmail.com
}

\begin{abstract}
Education has a very important role to prepare the nation's and religion's generation. Quality of education today is a very important for human life. The progress of a nation or state is depende on the education of a nation. Madrasah as educational institutions in Indonesia are educational institutions under the auspices of the Indonesian Ministry of Religion. Currently, madrasah are able to show that they are modern Islamic educational institutions that can be seen from their physical and academic appearance, madrasah already have complete infrastructure facilities to support scientific development (learning process), qualified educators according to their knowledge, good educational staff and other supporters. Madrasah also have the vision, mission and goals of the institution that must be considered in curriculum development. Each educational institution has varied differences, which show the strengths and opportunities of each educational institution. The facilities and facilities owned by the madrasah are the teacher's consideration in developing the curriculum. This requires madrasah as schools with Islamic characteristics in developing their curriculum to have scientific programs related to religion and science technology as well as soft skills, independence and leadership.
\end{abstract}

Key words: educational history, education system, Islamic educational institutions, madrasah.

\begin{abstract}
Abstrak: Pendidikan memiliki peran yang sangat penting dalam upaya mempersiapkan generasi bangsa dan agama. Pendidikan yang bermutu saat ini merupakan kebutuhan yang sangat penting dalam kehidupan manusia. Maju mundurnya suatu bangsa atau negara sangat tergantung pada pendidikan suatu bangsa tersebut. Madrasah sebagai lembaga pendidikan di Indonesia, merupakan lembaga pendidikan yang berada di bawah naungan Kementerian Agama Indonesia. Saat ini madrasah mampu menunjukan sebagai lembaga pendidikan Islam yang modern bisa dilihat dari tampilan fisik dan akademiknya, madrasah telah memiliki sarana prasarana yang lengkap sebagai pendukung pengembangan keilmuan (proses pembelajaran), tenaga pendidik yang mumpuni sesuai dengan keilmuannya (mapelnya), tenaga kependidikan yang baik serta pendukung lainnya. Madrasah juga memiliki visi, misi dan tujuan lembaga yang harus dipertimbangkan dalam pengembangan kurikulum. Setiap lembaga pendidikan memiliki perbedaan yang bervariasi, yang menunjukan kekuatan dan peluang masing-masing lembaga pendidikan. Sarana dan fasilitas yang dimiliki madrasah sebagai bahan pertimbangan guru dalam mengembangkan kurikulum. Hal ini menuntut madrasah sebagai sekolah yang bercirikhas Islam dalam mengembangkan kurikulumnya memiliki program-program keilmuan yang berkaitan dengan IMTAQ dan IPTEK serta membangun kecakapan, kemadirian dan kepemimpinan.
\end{abstract}

Kata Kunci: Lembaga pendidikan Islam, madrasah, sejarah pendidikan, sistem pendidikan 


\section{PENDAHULUAN}

Pendidikan merupakan salah satu faktor utama dalam upaya mempersiapkan generasi muda untuk menyambut dan menghadapi perkembangan zaman yang semakin kompetitif, sehingga lembaga pendidikan harus menjawab semua permasalahan baik yang bersifat lokal, nasional dan perubahan secara global yang begitu cepat. Pendidikan yang bermutu saat ini merupakan kebutuhan yang sangat penting dalam kehidupan manusia. Maju mundurnya suatu bangsa atau negara sangat tergantung pada pendidikan bangsa tersebut. ${ }^{1}$ Suatu bangsa atau negara dikatakan berperadaban tinggi apabila bangsa tersebut memberikan perhatian yang besar terhadap pendidikan.

Upaya menciptakan pendidikan yang berkualitas harus dilakukan, sebagaimana tercantum dalam UUD 1945 pada pasal 31 tentang sistem pendidikan nasional. Tujuan akhir pendidikan nasional secara umum adalah meningkatkan sumber daya manusia (SDM) yang berkualitas, seperti yang tercantum dalam UU No. 20 tahun 2003 tentang sistem pendidikan nasional (Sisdiknas) BAB II pasal 3 "Pendidikan nasional berfungsi mengembangkan kemampuan dan membentuk watak serta peradaban bangsa yang bermartabat dalam rangka mencerdaskan kehidupan bangsa, bertujuan untuk berkembangnya potensi peserta didik agar menjadi manusia yang beriman, bertaqwa kepada Tuhan Yang Maha Esa, berakhlak mulia, sehat, berilmu, cakap, kreatif, mandiri dan menjadi warga negara yang demokratis serta bertanggung jawab" 2

Di era globalisasi yang semakin luas, setiap bangsa perlu meningkatkan daya saingnya dalam berbagai bidang terutama sumber daya manusianya. Agar mampu bersaing setiap orang dituntut untuk mampu mengembangkan ilmu pengetahuan dan teknologi. Dalam rangka menjawab tantangan yang semakin berat lembaga pendidikan harus melakukan perubahan yang signifikan, dalam rangka mencetak sumber daya manusia yang mampu menjawab setiap perubahan.

Banyak hal yang menjadi permasalahan dan tantangan dunia pendidikan termasuk di dalamnya madrasah. Semua tantangan dan permasalahan yang dihadapi menuntut pemecahan yang serius, agar dapat menghasilkan sumber daya manusia yang berkualitas baik dari segi ilmu pengetahuan, teknologi serta berakhlakul karimah. Dalam hal ini, madrasah sebagai salah satu lembaga pendidikan Islam guna memenuhi tuntutan tersebut berupaya melakukan perubahan dan perkembangan secara terus-menerus guna menghasilkan lulusan yang berkualitas.

Pendidikan harus terus menerus melakukan penyesuaian dan pembenahan agar mampu mengikuti gerak perkembangan ilmu pengetahuan dan inovasi teknologi. Dengan begitu, pendidikan akan menjadi relevan dan kontekstual dengan perubahan zaman, oleh karena itu pendidikan harus menyiapkan peserta didik yang berkualitas agar dapat mencapai peradaban yang maju. Hal ini bisa terwujud melalui suasana belajar yang kondusif, kurikulum yang baik, aktivitas pembelajaran yang menarik serta proses pendidikan yang kreatif. ${ }^{3}$

Seiring dengan perkembangan keberadaan madrasah dalam dunia pendidikan di

\footnotetext{
${ }^{1}$ Ahmadi, Manajemen Kurikulum Pendidikan Kecakapan Hidup (Yogyakarta : Pustaka Ifada. 2013) 3

${ }^{2}$ Dirjen. Pendidikan Islam Departemen Agama RI, UU dan Peraturan Pemerintah RI tentang Pendidikan (Jakarta :

Dirjen. Pendidikan Islam, 2006) 8

${ }^{3}$ Ibid., 3
} 
Indonesia termasuk fenomena modern yaitu muncul pada abad ke- 20, sebagai lanjutan pembaruan pendidikan pesantren. Madrasah lahir juga sebagai bentuk lain dari pendidikan umum yang memposisikan diri sebagai lembaga pendidikan yang bercirikan agama Islam. Posisi ini diambil akibat ketidakpuasan masyarakat terhadap sistem pendidikan pesantren yang terbatas pada pengajaran ilmu-ilmu agama semata. ${ }^{4}$ Madrasah sebagai lembaga pendidikan umum yang berciri khas agama, dituntut untuk meningkatan kualitas sumber daya manusia baik peningkatan IMTAQ maupun IPTEK. Hal ini, terlihat jelas sejak awal pendidikan madrasah melalui SKB tiga menteri yaitu : Menteri Agama, Pendidikan dan Kebudayaan dan Dalam Negeri berusaha mensejajarkan kualitas lulusan madrasah sama dengan lulusan pendidikan umum lainnya. Pola kurikulum yang dikembangkan adalah 70 $\%$ bidang studi umum dan $30 \%$ bidang agama. Hal ini sesuai dengan Surat Keputusan Bersama (SKB) tiga menteri tahun 1975 Bab I Pasal 1, menyebutkan: "Yang dimaksud dengan madrasah dalam keputusan bersama ini ialah : Lembaga Pendidikan yang menjadikan mata pelajaran agama Islam sebagai dasar yang diberikan sekurangkurangnya $30 \%$, disamping mata pelajaran umum."5

Penjelasan diatas menunjukkan pentingnya peran madrasah dalam sistem pendidikan di Indonesia, khususnya sebagai lembaga yang mencerdaskan generasi bangsa. Maka dari itu, artikel ini bertujuan untuk mendeskripsikan sejarah perkembangan sistem pendidikan madrasah sebagai lembaga pendidikan Islam.

\section{PENELITIAN SEJARAH MADRASAH DI INDONESIA}

Ruslan Abdulghani mengemukakan bahwa sejarah adalah salah satu cabang ilmu yang meneliti dan menyelidiki secara sistematis keseluruhan perkembangan masyarakat, serta perkembangan kemanusiaan dimasa lampau, beserta segala kejadian-kejadianya dengan maksud untuk menilai secara kritis seluruh hasil penelitian dan penyelidikan tersebut untuk dijadikan pedoman masa sekarang dan proses masa yang akan datang. Begitu pula Menurut Kuntowijoyo yang dikutip Dudung, mengatakan bahwa peristiwa sejarah adalah mengenai apa saja yang dipikirkan, dirasakan, dikatakan dan dialami, atau secara metodologis sejarah merupakan pengungkapan fakta mengenai apa, siapa, kapan, dimana, bagaimana dan mengapa sesuatu terjadi. ${ }^{6}$ Begitu pula pendapat Sayyid Quthb yang dikutip Ramayulis, sejarah bukan hanya sekedar peristiwa melainkan penafsiran terhadap peristiwa-peristiwa tersebut. ${ }^{7}$

Pengertian selanjutnya makna sejarah sebagai catatan yang berhubungan dengan kejadian-kejadian masa lampau yang diabadikan dalam laporan tertulis dan dalam ruang lingkup yang luas. Sebagai cabang ilmu pengetahuan sejarah mengungkap peristiwaperistiwa masa silam, baik berkaitan masalah sosial, ekonomi, agama, budaya maupun perkembangan pendidikan dari suatu bangsa, negara atau dunia. ${ }^{8}$ Berdasarkan pemahaman diatas sejarah identik dengan peradaban manusia, melalui sejarah kita dapat

\footnotetext{
${ }^{4}$ Ahmadi, Manajemen Kurikulum Pendidikan Kecakapan Hidup (Yogyakarta : Pustaka Ifada, 2013) 159

${ }^{5}$ Haidar Putra Daulay, Sejarah Pertumbuhan dan Pembaruan Pendidikan Islam di Indonesia, (Jakarta : Kencana Prenada Media Group, 2007) 101

${ }^{6}$ Kuntowijoyo dalam Dudung Abdurrahman, Sejarah Peradaban Islam, Yogyakarta: LESFI, 2009) 5

${ }^{7}$ Sayyid Quthb dalam Ramayulis, Sejarah Pendidikan Islam, (Jakarta: Kalam Mulia, 2012) 1

${ }^{8}$ Zuhairini, Sejarah Pendidikan Islam, (Jakarta : PT Bumi Aksara, 2011) 2
} 
mengungkapkan serta memahami nilai-nilai yang terkandung dalam setiap peristiwa yang terjadi. ${ }^{9}$

Berdasarkan pengertian sejarah di atas bila dikaitkan dengan dunia pendidikan, maka sejarah pendidikan mengungkap semua fakta yang berhubungan dengan pertumbuhan dan perkembangan pendidikan.

Sejarah biasanya ditulis dan dikaji dari sudut pandang suatu fakta atau kejadian peradaban bangsa. Sehingga objek sejarah pendidikan Islam mencakup fakta-fakta yang berhubungan dengan pertumbuhan dan perkembangan pendidikan Islam baik formal, informal maupun non formal. Mengingat objek sejarah pendidikan Islam sangat sarat dengan nilai-nilai agamawi , filosofi, psikologi dan sosiologi, maka perlu menempatkan objek sasarannya utuh, menyeluruh dan mendasar. Sedangkan dalam sejarah pendidikan Islam metode yang dipakai yaitu :

1) Metode Deskriptif yaitu menggambarkan pendidikan Islam yang terjadi masa lampau. Dalam hal ini, diuraikan sebagaimana adanya dengan tujuan memahami makna yang terkandung dalam sejarah tersebut.

2) Metode Komparatif yaitu membandingkan perkembangan pendidikan Islam dengan perkembangan lembaga pendidikan yang lain.

3) Metode Analisis Sintetis yaitu menampakan kekhasan dan kelebihan pendidikan Islam. Sintesis di sini maksudnya adalah untuk memperoleh kesimpulan guna memperoleh kelengkapan kerangka pencapaian tujuan serta manfaat sejarah pendidikan Islam. ${ }^{10}$

\section{PENGERTIAN MADRASAH}

Kata 'Madrasah" berasal dari bahasa Arab asal kata dari "darasa, yadrusu, darsan dan madrasatan yang berarti tempat belajar para pelajar. ${ }^{11}$ Senada dengan Hasbullah, Harun Nasution et, al, kata madrsah berasal dari kata kerja darasa yang bearti belajar atau darrasa berarti mengajar. ${ }^{12}$ Ada pula yang mengartikan darasa adalah tempat duduk untuk belajar sebagaimana Poerwadarminta. ${ }^{13}$ Istilah Madrasah sekarang telah menyatu dengan istilah sekolah atau perguruan (terutama perguruan Islam). ${ }^{14}$ Sementara Karel A. Steenbrink dalam Enung K. Rukiati berpendapat antara madrasah dan sekolah berbeda alasannya bahwa sekolah dan madrasah memiliki ciri yang berbeda. ${ }^{15}$

Beberapa ahli berpendapat bahwa pengertian madrasah disamakan dengan sekolah karena secara teknis madrasah menggambarkan proses pembelajaran secara formal yang tidak berbeda dengan sekolah. Hanya saja secara kultural di Indonesia madrasah difahami lebih memiliki konotasi yang spesifik, dimana peserta didik memperoleh pembelajaran agama dan keagamaan lebih mendalam jika dibandingkan dengan sekolah pada umumnya. Dalam masyarakat madrasah lebih dikenal sebagai sekolah agama

\footnotetext{
${ }^{9}$ Dudung Abdurrahman, Sejarah Peradaban Islam, Yogyakarta: LESFI, 2009) 5

${ }^{10}$ Zuhairini, Sejarah Pendidikan Islam, (Jakarta : PT Bumi Aksara, 2011) 4

${ }^{11}$ Hasbullah, Sejarah Pendidikan Islam di Indonesia, (Jakarta : PT Raja Grafindo Persada, 1996) 160

${ }^{12}$ WJS. Poerwadarminta, Kamus Umum Bahasa Indonesia, (Balai Pustaka, 1990) 618

${ }^{13}$ Nasution,H, ensiklopedi Islam Indonesia, (Jakarta: Djambatan, 2002) 669

${ }^{14}$ WJS. Poerwadarminta, Kamus Umum Bahasa Indonesia, (Balai Pustaka, 1990) 618

${ }^{15}$ Enung K Rukiati dan Fenti H, Sejarah Pendidikan di Indonesia, (Bandung : Pustaka Setia, 2006)113
} 
dimungkinkan karena mata pelajaran agama lebih banyak.

\section{PERKEMBANGAN MADRASAH DI INDONESIA}

Syalaby dalam Daulay menjelaskan madrasah merupakan lembaga pendidikan yang tumbuh setelah masjid. Salah satu faktor yang menyebabkan tumbuhnya madrasah adalah karena masjid telah penuh dengan tempat belajar, hal ini dapat mengganggu aktivitas pelaksanaan ibadah shalat. Disamping itu menurut beliau pengetahuan mengalami perkembangan disebabkan perubahan zaman dan kemajuan peradaban manusia $^{16}$ Madrasah lahir juga sebagai bentuk lain dari pendidikan umum yang memposisikan diri sebagai lembaga pendidikan yang bercirikan agama Islam. Posisi ini diambil akibat ketidakpuasan masyarakat terhadap sistem pendidikan pesantren yang terbatas pada pengajaran ilmu-ilmu agama semata. ${ }^{17}$ Menurut Muhaimin dalam Enung K. Rukiyati, kehadiran madrasah sebagai lembaga pendidikan Islam setidaknya mempunyai beberapa latar belakang, diantaranya :

1) Sebagai manifestasi dan realisasi pembaharuan sistem pendidikan Islam.

2) Usaha penyempurnaan terhadap sistem pendidikan yang lebih memungkinkan lulusannya memperoleh kesempatan yang sama dengan sekolah umum, misalnya masalah kesamaan kesempatan kerja dan perolehan ijazah.

3) Adanya sikap mental pada sementara golongan umat islam, khususnya santri yang terpukau pada Barat sebagai sistem pendidikan modern dari hasil akulturasi. ${ }^{18}$

Keberadaan madrasah dalam dunia pendidikan di Indonesia termasuk fenomena modern yaitu muncul pada awal abad ke- 20, tumbuh kembangnya madrasah di Indonesia tidak bisa dipisahkan dengan tumbuh dan berkembangnya ide-ide pembaruan pendidikan dikalangan Umat Islam. Ide-ide pembaruan ini telah menginspirasi para ulama di Indonesia baik secara perorangan maupun organisasia keagamaan menggagas tumbuhnya madrasah di Indonesia.

Kemunculan Madrasah Adabiyah di Sumatra tahun 1908 dipelopori oleh Abdullah Ahmad, Syaikh M. Taib Umar mendirikan Madrasah School di Batusangkar pada tahun 1910 M, Madrasah Tawalib di Padang Panjang didirikan oleh Syaikh Abdul Karim tahun 1907 serta Madrasah Nurul Ulum di Jambi didirikan oleh H. Abdul Somad. Seperti halnya di Sumatra, di Jawa tahun 1912 muncul Madrasah Ibtida'iyah, Tsanawiyah, Mualimin, Mubalighin dan Madrasah Diniyah yang digagas oleh organisasi Muhammadiyah sebagai bentuk pendidikan yang mengapresiasi sistem pendidikan Belanda. Pada tahun $1913 \mathrm{Al}$ Irsyad mendirikan Madrasah Tajhiziyah, Mualimin dan Tahassus. Sebagai organisasi keagamaan, Pada tahun 1932 K.H. Abdul Halim dengan Perhimpunan Umat Islam (PUI) menggagas berdirinya lembaga pendidikan Islam di Majalengka Jawa Barat, madrasah ini disamping mengajarkan ilmu Agama juga dikemembangkan keterampilan baik keterampilan tangan, perdagangan serta bidang pertanian sesuai dengan bakat masing -

\footnotetext{
${ }^{16}$ Haidar Putra Daulay, Sejarah Pertumbuhan dan Pembaruan Pendidikan Islam di Indonesia. (Jakarta: Kencana Prenada Media Goup, 2007) 95

${ }^{17}$ Ahmadi, Manajemen Kurikulum Pendidikan Kecakapan Hidup (Yogyakarta : Pustaka Ifada, 2013) 159

${ }^{18}$ Enung K Rukiati dan Fenti H, Sejarah Pendidikan di Indonesia, (Bandung : Pustaka Setia, 2006)115
} 
masing. ${ }^{19}$ Pada tahun 1919, K.H. Hasyim Asy'ari sebagai salah satu tokoh pembabaharu pendidikan Islam di Jawa telah memperkenalkan madrasah dilingkungan pesantren Tebu Ireng Jombang Jawa Timur, beliau memperkenalkan sisten berkelas yang sebelumnya sistem sorogan dan bandongan, madrasah ini dikenal dengan nama Madrasah Salafiyah. Madrasah Salafiyah ketika dibawah kepemimpinan K. H. Ilyas dikembangkan menjadi madrasah yang tidak hanya mengajarkan ilmu agama dan bahasa Arab tetapi juga mengajarkan ilmu-ilmu umum dengan menggunakan buku tulis dan huruf latin. Diantara mata pelajaran yang dimasukkan dalam kurikulum Madrasah Salafiyah adalah ilmu bumi, Bahasa Indonesia, sejarah, ilmu hitung disamping membaca dan menulis huruf latin. Mahmud Yunus dalam Maksum memaparkan bahwa Madrasah Salafiyah Tebu Ireng Jombang dalam perkembangannya menawarkan dua pola pendidikan yaitu : 1) madrasah mengajarkan $75 \%$ pengajaran agama dan $25 \%$ pengajaran umum, 2) $25 \%$ pengajaran agama dan $75 \%$ pengajaran umum. ${ }^{20}$ selain itu Tebu Ireng juga banyak mendirikan madrasah diantaranya: Madrasah Awwaliyah, Madrasah Ibtidaiyah, Madrasah Tsanawiyah, Madrasah Mu'alimin Wusta, dan Madrasah Mu'alimin Ulya. ${ }^{21}$

Perkembangan madrasah di Indonesia tidak dapat dipisahkan dengan kebijakan pemerintah (penguasa) saat itu. Ketika berada di bawah kekuasan Belanda, pemerintah selalu mengawasi perkembangan pendidikan Islam dengan menerbitkan Ordonansi Guru (guru agama harus memiliki surat izin dari pemerintah). Kebijakan ini tidak hanya membatasi perkembangan pendidikan Islam saja akan tetapi yang paling penting adalah membatasi bahkan menghapus peran Islam di Indonesiia. Selain Ordonansi Guru pemerintah mengeluarkan Ordonasi Sekolah Liar (penyelenggara pendidikan harus mendapat izin dari pemerintah Belanda. ${ }^{22}$ Berbeda dengan Belanda, Jepang lebih koperatif dengan Islam untuk memperoleh dukungan dari Umat Islam. Jepang mengeluarkan kebijakan yang menawarkan bantuan untuk sekolah dan madrasah. Menanggapi kebijakan ini, Umat Islam merespon dan memanfaatkannya dengan sebaikbaiknya, hal ini bisa dilihat di Sumatra berdiri Madrasah Awwaliyah didirikan oleh Majelis Islam Tinggi Minangkabau yang dipimpin M. Jamil Jambek dan Mahmud Yunus. ${ }^{23}$

Madrasah - madrasah yang disebutkan di atas, menjadi bukti telah terjadi reformasi dalam lembaga pendidikan yang mulanya sistem sorogan, bandongan juga pendidikan dilakukan di masjid atau surau serta belum memiliki kurikulum yang jelas dan ada penjenjangan kini beralih menjadi sistem klasikal, kurikulumnya jelas dan berjenjang. Dalam bidang pengajaran pun mulai ada perubahan dari hanya bidang agama saja ditambah dengan pengajaran umum.

Menurut Timur Jaelani dalam Ramayulis, Perkembangan pendidikan madrasah mendapat perhatian pemerintah setelah Indosesia merdeka. Badan Pekerja Komite Nasional Pusat (BPKNP) tanggal 27 Desember 1945, menyebutkan bahwa madrasah

\footnotetext{
${ }^{19}$ Haidar Putra Daulay, Sejarah Pertumbuhan dan Pembaruan Pendidikan Islam di Indonesia. (Jakarta: Kencana Prenada Media Group, 2007) 97-99

${ }^{20}$ Maksum, Madrasah, Sejarah dan Perkembangannya, (Jakarta : Logos Wacana Ilmu, 1999)110

21 Ibid,

22 Ibid, 116

${ }^{23} \mathrm{Ibid}, 117$
} 
hakikatnya adalah sumber pendidikan dan pencerdasan rakyat hendaknya mendapat perhatian dan bantuan dari pemerintah. ${ }^{24}$

Madrasah sebagai lembaga pendidikan diakui secara formal pada tahun 1950 dalam UUD No. 4 tahun 1950 tentang dasar Pendidikan dan Pengajaran di sekolah pada pasal 10 disebutkan "Belajar di sekolah agama yang telah mendapat pengakuan Kementerian Agama sudah dianggap memenuhi kewajiban belajar". Untuk mendapatkan pengakuan, maka pendidikan agama (madrasah)harus memberikan pelajaran agama paling sedikit 6 jam seminggu sebagai pelajaran pokok. Sehingga pada tahun 1950 Kementrian Agama di bawah Menteri Agama K. H. Wahid Hasyim membuka Madrasah Wajib Belajar (MWB). Tujuan MWB diarahkan pada pengembangan jiwa bangsa yaitu kemajuan ekonomi, industri dan transmigrasi dengan kurikulumnya menyangkut tiga perkembangan yaitu : Perkembangan otak, Perkembangan hati dan Perkembangan keterampilan tangan (Three $\mathrm{H}$ : heart, Heard and hand). ${ }^{25}$ Hanya saja perkembangan MWB tidak sesuai dengan harapan karena ada beberapa faktor kendala yaitu : 1) Keterbatasan sarana dan prasarana, 2) Ketidaksiapan pemerintah mempersiapkan guru, 3) Kurangnya antusiasme masyarakat dan penyelenggara madrasah, 4) Masyarakat beranggapan porsi pelajaran agama $25 \%$ kurang memenuhi syarat sebagai lembaga pendidikan agama

Untuk memenuhi kebutuhan tenaga pengajar, pada tahun 1950 Departemen Agama melalui penaggung jawab Bagian Pendidikan membuka dua lembaga pendidikan dan madrasah profesional keguruan yaitu 1) Sekolah Guru Agama Islam (SGAI) dan 2) Sekolah Guru Hakim Agama Islam (SGHAI). Pada tahun 1951 melalui surat Ketetapan Menteri Agama tanggal 15 Februari 1951, kedua madrasah tersebut dirubah namanya dari SGAI menjadi PGA (Pendidikan Guru Agama) dan SGHAI menjadi SGHA (Sekolah Guru Hakim Agama). ${ }^{26}$

Upaya untuk meningkatkan mutu madrasah terus berkembang. Perubahan selanjutnya terjadi pada masa Departemen Agama dipimpin oleh Dr. Mukti Ali, M.A beliau bekerjasama dengan Menteri Dalam Negeri dan Menteri Pendidikan dan Kebudayaan mengeluarkan Surat Keputusan Bersama No. 6 tahun 1975, No. O37/ U /1975 dan No. 36 tahun 1975 tanggal 24 Maret 1975 tentang Peningkatan Mutu Pendidikan Madrasah. SKB 3 menteri ini merupakan pelaksanaan dari Kepres No. 15 tahun 1972 dan Instruksi Presiden No. 15 tahun 1974, hal ini sesuai dengan petunjuk presiden pada sidang kabinet tanggal 26 November 1974. Yang dimaksud madrasah dalam SKB 3 Menteri adalah lembaga pendidikan yang menjadikan mata pelajaran agama Islam sebagai mata pelajaran dasar yang diberikan sekurang-kurangnya $30 \%$ disamping pelajaran umum. ${ }^{27}$ SKB 3 Menteri ini diperkuat SKB 2 Menteri antara Menteri Pendidikan dan Kebudayaan dengan Menteri Agama, dengan diterbitkannya Surat Keputusan Menteri Pendidikan dan Kebudayaan No. 0299/U/1984 dan Surat Keputusan Menteri Departemen Agama No. 045 tahun 1984 tentang Pengaturan Pembakuan Kurikulum Sekolah Umum dan Madrasah. Berdasarkan SKB 2 Menteri lahirlah

\footnotetext{
${ }^{24}$ Ramayulis, Sejarah Pendidikan Islam, (Jakarta : Kalam Mulia, 2011)347

${ }^{25} \mathrm{Ibid}, 350$

${ }^{26} \mathrm{Ibid}, 352$

${ }^{27} \mathrm{Ibid}, 355$
} 
kurikulum 1884 untuk madrasah melalui Keputusan Menteri Agama Nomor. 99 tahun 1984 untuk Madrasah Ibtidaiyah, No. 100 tahun 1984 untuk Madrasah Tsanawiyah dan Nomor 101 tahun 1984 untuk Madrasah Aliyah. ${ }^{28}$

Pada tahun 1989 pemerintah mengeluarkan Undang -undang No. 2 tahun 1989 tentang Sistem Pendidikan Nasional (SISPENAS), setelah diberlakukannya undangundang tersebut maka dikeluarkanlah Surat Keputusan Menteri Agama Nomor 372 tahun 1993 tentang Kurikulum Pendidikan Dasar berciri Khas Agama terdiri Madrasah Ibtidaiyah dan Madrasah Tsanawiyah (MI dan MTs) dan Nomor 373 tahun 1993 tentang Kurikulum Pendidikan menengah berciri Khas Agama yaitu Madrasah Aliyah. ${ }^{29}$ Departemen Agama terus melakukan pengembangan Madrasah Aliyah, ketika Menteri Agama di pimpin oleh Prof. Munawir Sadzali, MA membukan Madrasah Aliyah Program Khusus (MAPK) dalam rangka mengatasi kelangkaan ulama yang tafaqquh fi al-din. Pembukaan MAPK tertuang dalam Surat Keputusan Menteri Agama Nomor 371 tahun 1993, yang kurikulumnya tertuang pada Surat Keputusan Menteri Agama Nomor 374 tahun 1993.

Dalam rangka memenuhi tuntutan dari UU tentang SISPENAS, Departemen Agama disatu sisi bertanggung jawab sebagai lembaga pendidikan umum harus sama dengnan sekolah-sekolah umum, tetapi disi lain madrasah memiliki tanggung jawa sebagai lembaga pendidikan yang berciri khas Islam. Oleh karena itu Departemen Agama mengeluarkan ketentuan tentang kurikulum madrasah yaitu kurikulum madrasah yang berlaku secara nasional berdasarkan Surat Keputusan Menteri Agama Nomor. 371 tahun 1993 tentang kurikulum Madrasah Tsanawiyah dan Nomor 373 tahun 1993 tentang Kurikulum Madrasah Aliyah. Kurikulum mulai diberlakukan pada tahun 1994. ${ }^{30}$

Setelah runtuhnya Orde Baru dan digantikan Era Reformasi, menurut Ramayulis perkembangan madrasah dapat dibagi dua periode:

1) Perkembangan madrasah masa reformasi dengan adanya Otonomi Daerar dan Disentralisasi Pendidikan, terjadi perubahan dalam pengelolaan, pemberdayaan dan partisifasi masyarakat.

2) Perkembangan madrasah dalam pelaksanaan Undang-Undang Nomor 20 tahun 2003 tentang SISDIKNAS. Madrasah merupakan jenis pendidikan umum sebagaimana tercantum pada pasal 17 ayat 2 dan 3. Departemen Agama terus memperbaiki mutunya sebagaimana yang dikehendaki SISDIKNAS yaitu meningkatkan mutu pendidikan yang dilaksanakan secara berencana dan berkala, dan berdasarkan atas standar nasional sebagai acuan pengembangan kurikulum, tenaga pendidik, sarana, pengelolaan dan pembiayaan pendidikan seperti yang tercantum pada pasal 35 ayat $92 .{ }^{31}$

\footnotetext{
${ }^{28} \mathrm{Ibid}, 357$

${ }^{29}$ Depag RI, Panduan Kurikulum Madrasah Aliyah 1994 (Depag. RI, 1994),137

${ }^{30}$ Ramayulis, Sejarah Pendidikan Islam, (Jakarta : Kalam Mulia, 2011)347

${ }^{31}$ Ibid, 363-367
} 


\section{MADRASAH SEBAGAI SEKOLAH BERCIRI KHAS AGAMA}

Keberadaan madrasah sebagai lembaga pendidikan Islam di Indonesia, menurut para ahli pendidikan, khususnya dalam bidang sejarah pendidikan Islam, seperti Azyumardi Azra, Maksum, Hasbullah, Steenbrink, Nakosteen, dan lain-lain, sebenarnya bukan merupakan satu mata rantai sejarah tumbuh dan berkembangnya madrasah di masa Islam Klasik. Tetapi madrasah di Indonesia muncul sebagai kelanjutan logis lembaga pendidikan Islam sebelumnya, khususnya Jawa, yaitu pesantren. Pandangan ini, diperkuat oleh suatu kenyataan bahwa masuknya Islam ke Nusantara, baik gelombang pertama (abad ke-7 M) maupun gelombang kedua (abad ke-13 M) tidak diikuti oleh muncul atau berdirinya madrasah. Dengan alasan itu pula, maka secara historis menurut Nurcholish Madjid, pesantren seringkali disebut tidak hanya identik dengan makna keislaman, tetapi juga mengandung makna keaslian Indonesia (indigenous).

Istilah madrasah dalam berbagai penggunaannya sebenarnya mempunyai banyak pengertian dan ruang lingkup. Namun yang perlu digaris bawahi adalah madrasah dalam pengertian sebagaimana sistem perundang-undangan kita yang terdapat dalam keputusan Menteri Agama dan Menteri Dalam Negeri yang mengatur tentang madrasah, yaitu bahwa madrasah sebagai lembaga pendidikan agama Islam yang di dalam kurikulumnya memuat materi pelajaran agama dan pelajaran umum, di mana mata pelajaran agama lebih banyak dibandingkan dengan mata pelajaran agama pada sekolah umum.

Dalam perkembangannya madrasah dituntut agar selalu berproses untuk menjadi besar, mekar dan berkembang, tersebar luas dan bertambah banyak, serta semakin sempurna dengan tujuan dasarnya untuk mencerdaskan, menghilangkan ketidaktahuan, melenyapkan kebodohan serta membekali anak didik dengan kompetensi, untuk menghadapi tantangan zaman yang terus mengalami perubahan di berbagai sektor kehidupan, termasuk juga arus globalisasi yang tidak terbendung.

Untuk menghadapi tantangan yang semakin berat, madrasah tentu harus bekerja keras untuk mewujudkan madrasah yang Islami, Populis, Berkualitas dan beragam. Maksudnya adalah : Pertama, Islami merupakan gambaran bahwa madrasah tidak bisa dilepaskan dari pembelajaran agama yang menjadi ciri kekhasannya (identitas) yang melekat dan inilah yang membedakan antara madrasah dan sekolah. Kedua, Populis merupakan gambaran bahwa madrasah itu lahir dan dibesarkan oleh dan untuk masyarakat. Ketiga, Berkualitas; artinya berorientasi pada mutu. Hal ini merupakan tantangan masa depan yang sangat nyata, karena penghargaan masyarakat terhadap sebuah lembaga pendidikan sangat ditentukan oleh tingkat kualitas pendidikannya. Kualitas pendidikan itu tercermin dalam dua tataran: proses pendidikan dan hasil pendidikan. Proses pendidikan menggambarkan suasana pembelajaran yang aktif dan dinamis serta konsisten dengan program dan target pembelajaran. Sedangkan hasil pendidikan menunjuk pada kualitas lulusan dalam bidang kognitif, afektif, dan psikomotorik. Jika gagal dalam mewujudkan visi ini, madrasah akan tertinggal dari lembaga-lembaga pendidikan lain. Berkualitas dicerminkan pada kegiatan dan nilai akademik yang diperoleh madrasah tersebut. Baik yang dapat dan dilihat dari hasil belajar siswa berupa nilai pada ulangan, kenaikan kelas, ujian akhir, maupun ujian masuk perguruan tinggi (UMPTN). Keempat, Beragam, madrasah menyediakan berbagai jurusan 
keahlian (jurusan) sesuai dengan bakat dan minat masing-masing peserta didik.

\section{PERUBAHAN KURIKULUM MADRASAH DI INDONESIA}

Perjalanan kurikulum di Indonesia sering terjadi perubahan, hal ini merupakan konsekuensi dari adanya perubahan politik, sosial, budaya, ekonomi, ilmu pengetahuan dan teknologi dalam masyarakat berbangsa dan bernegara. Kurikulum sebagai seperangkat rencana pendidikan terus mengalami perubahan sesuai dengan tuntutan dan perubahan yang terjadi di masyarakat. kurikulum nasional dirancang berdasarkan landasan yang sama, yaitu Pancasila dan UUD 1945, perbedaannya pada penekanan pokok dari tujuan pendidikan serta pendekatan dalam merealisasikannya. ${ }^{32}$

Madrasah sebagai bagian dari lembaga pendidikan yang ada di Indonesia, sejak terbitnya Surat Keputusan Bersama (SKB) 3 menteri No. 6 tahun 1975 dan No. 037/U/1975 antara Menteri Pendidikan dan Kebudayaan, Menteri Agama, dan Menteri Dalam Negeri, tentang peningkatan mutu pendidikan madrasah. Dalam SKB 3 Menteri yang dimaksud madrasah adalah lembaga pendidikan yang menjadikan mata pelajaran agama Islam sebagai mata pelajaran dasar yang diberikan sekurang-kurangnya $30 \%$ disamping pelajaran umum. Melalui SKB 3 Menteri ditetapkan hal-hal yang menguatkan madrasah sebagai bagian dari lembaga pendidikan, diantaranya :

1) Ijazah madrasah mempunyai nilai yang sama dengan ijazah sekolah umum yang setingkat.

2) Lulusan madrasah dapat melanjutkan kejenjang yang lebih tinggi.

3) Siswa madrasah dapat pindah ke sekolah umum yang setingkat.

Mengenai pengelolaan dan pembinaan madrasah, diatur sebagai berikut :

1) Pengelolaan madrasah dilakukan oleh Menteri Agama

2) Pembinaan mata pelajaran agama pada madrasah dilakukan oleh Menteri Agama

3) Pembinaan dan pengawasan mutu mata pelajaran umum pada madrasah dilakukan oleh Menteri Pendidikan dan Kebudayaan bersama-sama dengan Menteri Agama dan Menteri Dalam Negeri. ${ }^{33}$

Kurikulum 1975 menekankan pada tujuan, agar pendidikan lebih efisien dan efektif. "Yang melatarbelakangi adalah pengaruh konsep di bidang manejemen, yaitu MBO (management by objective). Metode, materi, dan tujuan pengajaran dirinci dalam Prosedur Pengembangan Sistem Instruksional (PPSI). Zaman ini dikenal istilah "satuan pelajaran", yaitu rencana pelajaran setiap satuan bahasan. Setiap satuan pelajaran dirinci lagi: tujuan instruksional umum (TIU), tujuan instruksional khusus (TIK), materi pelajaran, alat pelajaran, kegiatan belajar-mengajar, dan evaluasi. Sebagai tindak lanjut dari SKB 3 Menteri, pada tahun 1976 Departemen Agama menetapkan kurikulum standar untuk menjadi acuan madrasah berdasarkan keputusan Menteri Agama No. 75 tanggal 29 Desember 1976, yang diberlakukan pada tahun 1978. Kurikulum 1976 berisi tentang

\footnotetext{
${ }^{32}$ Maksum, Madrasah, Sejarah dan Perkembangannya, (Jakarta : Logos Wacana Ilmu, 1999)150

${ }^{33}$ Ibid-150-151
} 
peningkatan mutu madrasah, agar berimbang antara ilmu-ilmu agama, ilmu sosial, ilmu alam serta humaniora.

Tahun 1984 muncul kurikulum baru yang dikenal kurikulum 1984, kurikulum ini merupakan penyempurnaan kurikulum 1976. Kurikulum 1984 berorientasi kepada tujuan instruksional, didasari oleh pandangan bahwa pemberian pengalaman belajar kepada siswa dalam waktu belajar yang sangat terbatas di sekolah harus benar-benar efektif. Pendekatan pengajarannya berpusat pada anak didik melalui Cara Belajar Siswa Aktif (CBSA) atau Student Active Leaming (SAL). Penyusunan kurikulum madrasah 1984 berdasarkan Surat Keputusan Bersama (SKB) dua menteri yaitu, Menteri Pendidikan dan Kebudayaan No. 0299/U/1984, dan Menteri Agama No. 045/1984 tentang pengaturan pembakuan kurikulum sekolah umum dan kurikulum madrasah. hasil SKB dua menteri ini isinya tentang penyamaan mutu lulusan madrasah yang dapat melanjutkan pendidikan ke sekolah-sekolah yang lebih tinggi. Dengan terjadinya perubahan kurikulum, maka Departemen Agama mengeluarkan Surat Keputusan Menteri Agama Nomor 101 tahun 1984 tentang kurikulum madrasah aliyah. Struktur kurikulum 1984 ditingkat aliyah terdiri dari lima jurusan yaitu : 1) A1 (Ilmu-ilmu Agama), 2) A2 (Ilmu-ilmu Fisika). 3) A3 (Ilmu-ilmu Biologi). 4) A4 (Ilmu-ilmu Sosial), 5) A5 (Pengetahuan Budaya). Pada komponen kurikulum 1984 tingkat aliyah terbagi menjadi dua program yaitu : Program Inti dan Program Pilihan. Yang termasuk Program Inti adalah Pendidikan Agama yang mencakup lima mata pelajaran (fiqih, Quran Hadhits, Aqidah Akhlak, SKI dan Bahasa Arab) dan pendidikan Dasar Umum terdiri dari 19 mata pelajaran (PKn, Bahasa Indonesia, bahasa Inggris, matematika, fisika, kimia, biologi, geografi, ekonomi, sosiologi, penjaskes, serta TIK). ${ }^{34}$

Tahun 1994 lahir kurikulum baru yang dikenal kurikulum 1994, kurikulum ini merupakan penyempurnaan kurikulum 1984. Kurikulum 1994 dilaksanakan sesuai dengan Undang-Undang no. 2 tahun 1989 tentang Sistem Pendidikan Nasional. Diberlakukannya kurikulum 1994 berdampak pada sistem pembagian waktu pelajaran, yaitu dengan mengubah dari sistem semester ke sistem caturwulan. Tujuan pengajaran menekankan pada pemahaman konsep dan keterampilan menyelesaikan soal dan pemecahan masalah. dilaksanakannya kurikulum 1994 muncul beberapa permasalahan, di antaranya adalah beban belajar siswa terlalu berat karena banyaknya mata pelajaran dan banyaknya materi/substansi setiap mata pelajaran. ${ }^{35}$ Hal ini mendorong para pembuat kebijakan untuk meninjau kembali tingkat keberhasilan kurikulum 1994. Tahun 2004 terjadi perubahan kurikulum yang dikenal dengan Kurikulum Berbasis Kompetensi (KBK).

\footnotetext{
${ }^{34}$ Ibid, 145

${ }^{35}$ http://lilisdisdik.wordpress.com/2012/10/30/perubahan-kurikulum/tgl. 30 Maret 2014
} 


\section{KESIMPULAN}

Madrasah sebagai lembaga pendidikan yang berada di bawah naungan Kementerian Agama, dengan semangat dan kerja keras yang dilakukan seluruh warganya kini mampu menunjukan sebagai lembaga pendidikan Islam yang modern bisa dilihat dari tampilan fisik dan akademiknya, madrasah telah memiliki sarana prasarana yang lengkap sebagai pendukung pengembangan keilmuan (proses pembelajaran), tenaga pendidik yang mumpuni sesuai dengan keilmuannya (mapelnya), tenaga kependidikan yang baik serta pendukung lainnya. Madrasah juga memiliki visi, misi dan tujuan lembaga yang harus dipertimbangkan dalam pengembangan kurikulum. Setiap lembaga pendidikan memiliki perbedaan yang bervariasi, yang menunjukan kekuatan dan peluang masingmasing lembaga pendidikan. Sarana dan fasilitas yang dimiliki madrasah sebagai bahan pertimbangan guru dalam mengembangkan kurikulum. Hal ini menuntut madrasah sebagai sekolah yang bercirikhas Islam dalam mengembangkan kurikulumnya memiliki program-program keilmuan yang berkaitan dengan IMTAQ dan IPTEK serta membangun kecakapan, kemadirian dan kepemimpinan.

\section{DAFTAR PUSTAKA}

Abdurrahman, Dudung, Sejarah Peradaban Islam, Yogyakarta: LESFI, 2009

Ahmadi, Manajemen Kurikulum Pendidikan Hidup, Yogyakarta : Putaka Ifada, 2013

Daulay, Haidar Putra, Sejarah Pertumbuhan dan Pembaharuan Pendidikan Isladi Indonesia, Jakarta : Kencana Prenada Media Group, 2007

Dirjen Pendidikan Islam Departemen Agama RI, UU dan Peraturan Pemerintah RI tentang Pendidikan, Jakarta : Dirjen Pendidikan Islam, 2006

Hasbullah, Sejarah Pendidikan Islam di Indonesia, Jakarta: PT. Raja Grafindo Persada, 1996

http://Aminnatul-widyono.blogspot.com/2011/07/pendidikan-dan-perubahan,sosial,html, diakses 17 November 2013

http://ardabillya.wordpress.com/landasan-pengembangan-kurikulum, diakses 27 April 2014

http://mudjiarahardjo,uin-malang.ac.id/materi-kuliah/288-metode-pengumpulan-data-

penel itian-kualitatif, diakses 2 Juli 2014

http://nasional,kompas.com/read2014/01/14/18325/mendikbud-kurikulum-berubahsesuai- perkembangan-zaman, diakses 23 April 2014

http://peta-kota.blogspot.com/2011/07/peta-kabupaten-ponorogo.html diakses 22 Juli 2014

http://www.humasponorogo.com/2012/03/visi-misi-dan-mott.html diakses 23 Juli 2014 
Maksum, Madrasah, Sejarah dan Perkembangannya, Jakarta: Logos Wacana Ilmu, 1999

Nasution, H, Ensiklopedi Islam Indonesia, Jakarta: Djambatan, 2002

Poerwadarminta,WJS, Kamus Umum Bahasa Indonesia, Jakarta: Balai Pustaka, 1990

Qutub, Sayyid, Konsepsi Sejarah Dalam Islam, Jakarta : Yayasan Al Amin, t,t

Ramayulis, Sejarah Pendidikan Islam, Jakarta :Kolam Mulia, 2012

Rukiati dan Fenti, Sejarah Pendidikan di Indonesia, Bandung : Pustaka Setia, 2006

Zuhairini, Sejarah Pendidika Islam, Jakarta : PT. Bumi Aksara, 2011 